\title{
Middle Income Trap: The Ignored Role of Women
}

Leyla Firuze ARDA-ÖZALP (https://orcid.org/0000-0001-9654-8043), Department of Economics, Amasya University, Turkey; e-mail: leyla.ozalp@amasya.edu.tr

\section{Orta Gelir Tuzağı: Kadınların Göz Ardı Edilen Rolü}

\begin{abstract}
This paper estimates the links between the middle-income trap and women's employment with the dataset of 27 middle-income countries for 22 years. In line with the study's prime objective, a panel logit regression model is used. The findings based on the conditional fixed-effects logistic regression show that the possibility of a middle-income country being a high-income economy is significantly associated with women's employment rate, productivity, innovation, and institution. The results also show that female employment is an argument of escape strategy that has more impact than other variables.
\end{abstract}

Keywords : Middle Income Trap, Growth, Women's Employment, Panel Data, Logistic Regression.

JEL Classification Codes : O10, 030, J16.

\section{Öz}

Bu makale, orta gelir tuzağı ve kadın istihdamı arasındaki ilişkiyi, 22 yıllık dönem için 27 orta gelirli ülkenin veri setiyle tahmin etmektedir. Çalışmanın temel amacı doğrultusunda panel logit regresyon modeli kullanılmıştır. Lojistik regresyona bağlı bulgular, orta gelirli bir ülkenin yüksek gelirli bir ekonomi olma olasılığının, kadın istihdam oranı, verimlilik, yenilik ve kurumlar ile önemli ölçüde ilişkili olduğunu göstermektedir. Bununla birlikte, sonuçlar kadın istihdamının diğer değişkenlerden daha fazla etkiye sahip bir kaçış stratejisi argümanı olduğunu da göstermektedir.

Anahtar Sözcükler Orta Gelir Tuzağı, Büyüme, Kadın İstihdamı, Panel Veri, Lojistik Regresyon. 


\section{Introduction}

After the period of rapid growth, many countries have achieved a middle-income level but unfortunately, the majority of them have failed to become high-income countries. In the early 1900s, The USA had the largest national income in the world. But income differences between countries were not so high. In this period, Canada, Belgium, Argentina's GDP per capita was around between \$ 5000 and \$ 7000. But now Argentina has almost 18000 GDP per capita while Canada has about 42000. Since the 1950s income differences across countries have become crystallized. Many countries like China, Argentina, Turkey, or Brazil enjoyed fast income growth and they reach the middle-income status. Unlike them, South Korea managed to become a high-income country. South Korea did not even have \$ 1000 in national income in the early 1900s. But now per capita income is almost $\$ 36000$.

The expression of the "middle-income trap" is first offered by Gill \& Kharas (2007) to explain clearly the becoming stuck in the middle-income status. Following this study, many studies have been conducted on the middle-income trap. As in the study by Agénor \& Canuto (2012), this development literature mainly focusses on the productivity slowdowns as a major cause of middle-income traps (Daude \& Fernandez-Arias, 2010; Eichengreen et al., 2012; 2013; Wu, 2014; Lee \& Narjoko, 2015; Vivarelli, 2015). Although technology, innovation, or productivity are accepted as the core of the middle-income trap problem, different approaches are presented in the literature. This issue is also evaluated in terms of arguments such as institutions, income inequality, and macroeconomic structure (Wang, 2016; Köse \& Çınar, 2018; Zou, 2018; Kabir \& Ahmed, 2019). The study by Mare et al. (2015), to the best of our knowledge, is the first and only study regarding gender issues in the middle-income trap. Although there are many studies which analyse the middle-income trap, a limited number of study analyses women's employment status in the middle-income countries. Thus, this paper differs from existing middle-income trap literature because of considering the gender issues. This paper agrees with all valuable views about innovation and productivity but extends it in a different aspect drawing attention to the ignored role of women. Because besides all these reasonable explanations, there is another difference between high-income and middle-income countries. In all high-income countries, the women's employment rate is enough high and so their contribution to the economy is also as high as possible. But in middle-income countries, women's employment is mostly an unused resource. So, we can consider women's employment as another escape strategy from the middle-income trap.

To assess the middle-income trap, this study runs a data set for 27 countries for the period from 1995 to 2016. This paper is structured as follows: In the first section of the paper, the concept of the middle-income trap is discussed. In the second section of the paper, the differences in women's employment status between high-income and middle-income countries are evaluated. In the third section of the paper related literature is presented. And finally, a logit model is used to estimate the effect of the women's employment and other related variables on escaping the middle-income trap. The final section includes concludes. 


\section{The Concept of The Middle-Income Trap}

In the World Bank Report (2007) on the East Asian economies, named "An East Asian Renaissance: Ideas for Economic Growth", Gill \& Kharas (2007) offer the phenomenon called the middle-income trap into the development literature and describe this phenomenon as "the economies that were being squeezed between the low-wage poor country competitors that dominate in mature industries and the rich-country innovators that dominate in industries undergoing rapid technological change".

Since the 1950s, many countries have become middle-income economies thanks to rapid growth, but very few have managed to be high-income countries. Following a period of rapid economic growth, the majority of them have experienced a slowdown and they have become caught in the middle-income trap. Some advantageous factors such as low-cost labor and easy technology adoption that promoted growth in these countries during their period of rapid development lost their effect when they reached middle-income levels. Many countries from Latin America and the Middle East serve as a model for the middle-income trap hypothesis. Most economies from these regions reached middle-income in the 1960s and remained there. Malaysia and Thailand are all suitable samples of the slowdown and becoming stuck. According to the World Bank estimates (2013), out of 101 middle-income economies in the 1960s, only 13 managed to be a high-income economy by 2008 (Agénor \& Canuto, 2015; Agénor et al. 2012; World Bank, 2013).

The middle-income trap can explain as "a trap of policy misdiagnosis" that middleincome countries could fall into when failed to match their economic growth strategies with structural properties. In the initial period of development, low-income countries could exist as a competitor in international markets by exporting labour-intensive and lower-cost products with the imported technologies. However, once they reach middle-income levels, their productivity growth begins to lose power. And then rising wages cause the labourintensive products to lose their competitive edge in international markets. There are two types of traps that middle-income countries could come across; (1) middle-income countries trying to sustain the labour-intensive manufacturing as a growth strategy although they have a competitive disadvantage is driven by high wages, (2) middle-income countries without institutional infrastructure trying to be knowledge economies ahead of time. They have lots of barriers to becoming an innovation economy such as poor-quality educations, low levels of human capital, limited venture capital, regulatory barriers, and insufficient rule of law (Agénor et al., 2012; Gill \& Kharas, 2015).

There are two commonly accepted specifications for income classifications of countries. The first specification is provided by World Bank. World Bank classification follows these categories ${ }^{1}$;

See, <https://datahelpdesk.worldbank.org/knowledgebase/articles/906519-world-bank-country-and-lendinggroups $>$, 18.08.2020. 
- low-income economies: $\$ 1,025$ or less,

- lower-middle-income economies: between $\$ 1,026$ and $\$ 3,995$,

- upper-middle-income economies: between $\$ 3,996$ and $\$ 12,375$,

- and high-income economies: \$12,376 or more in 2018.

The second specification is developed by Woo (2011) is based on the ratio of the income level of the country to the income level of the US is known as the economic leader of the world since the 1920s (Woo 2012). This comparative approach called Catch-Up Index (CUI) follows these categories.

- high-income economies; CUI > 55\%,

- middle-income economies; $55 \%>\mathrm{CUI}>20 \%$,

- low-income economies; CUI $<20 \%$.

Figure 1 shows the comparison of the income level of the countries to the income level of the US from 1923 to 2016. This comparison based on the specification by Woo (2011) underline that the countries such as Turkey, Brazil, and China reached the middleincome status from low-income level and remained there ever since $(55 \%>$ middle income level > 20\%).

\section{Figure: 1}

\section{GDP Per Capita to US (Real GDP per capita in 2011US\$)}

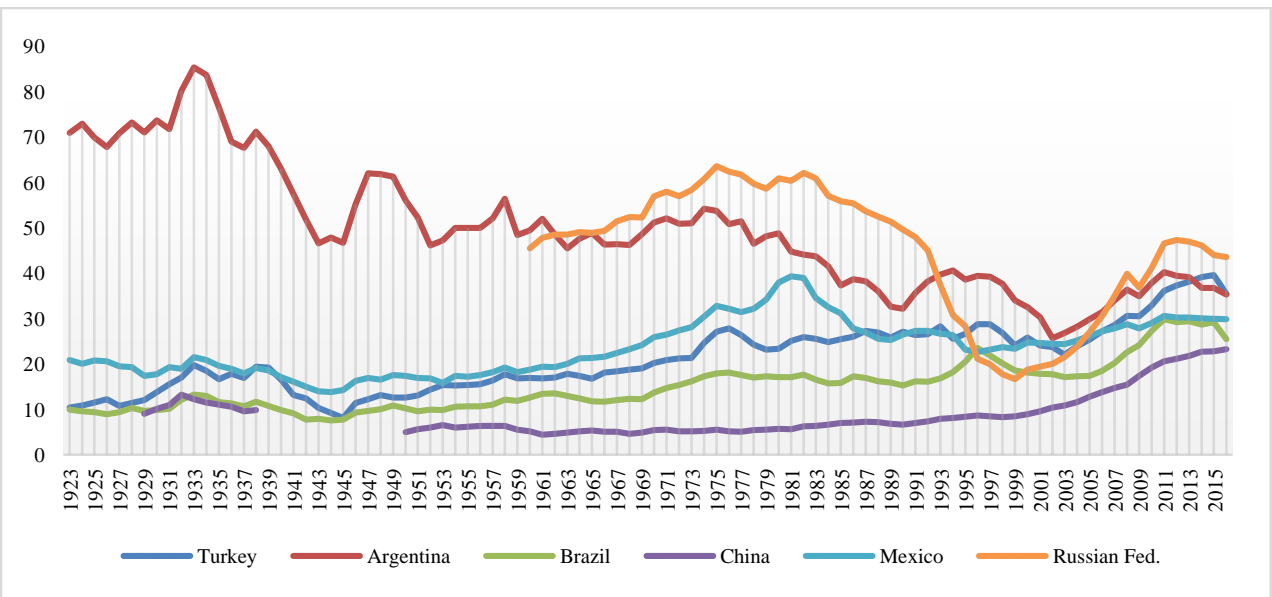

Source: Maddison Project Database, version 2018.

\section{Comparison of the Women's Employment Status}

Women's employment rate increased in many countries, especially in the western world in the last 30-40 years or more. Even in countries with low female employment in the 80s, women's employment has increased significantly today. In the Netherlands, women's 
employment to the population increased from $34 \%$ in 1980 to $77 \%$ in 2018. Similarly, in Spain and Italy, it increased respectively from 28\%; 33\% in 1980 to 57\%; $49 \%$ in 2018. Today, the women's employment rate is high in many western high-income countries, and the gap between men's and women's employment has declined compared to the past. The 2018 average women's employment rate of 30 OECD member Western countries is about $67 \%$ and the employment gap between men and women is around $8 \%$. Table 1 shows the trajectory of the gender gap in employment in selected western countries since 1980. The trajectory of the gender gap in employment of these countries tends to decline markedly (<https://stats.oecd.org/>).

Figure: 2

\section{Gender Employment Gap in Selected Western Countries}

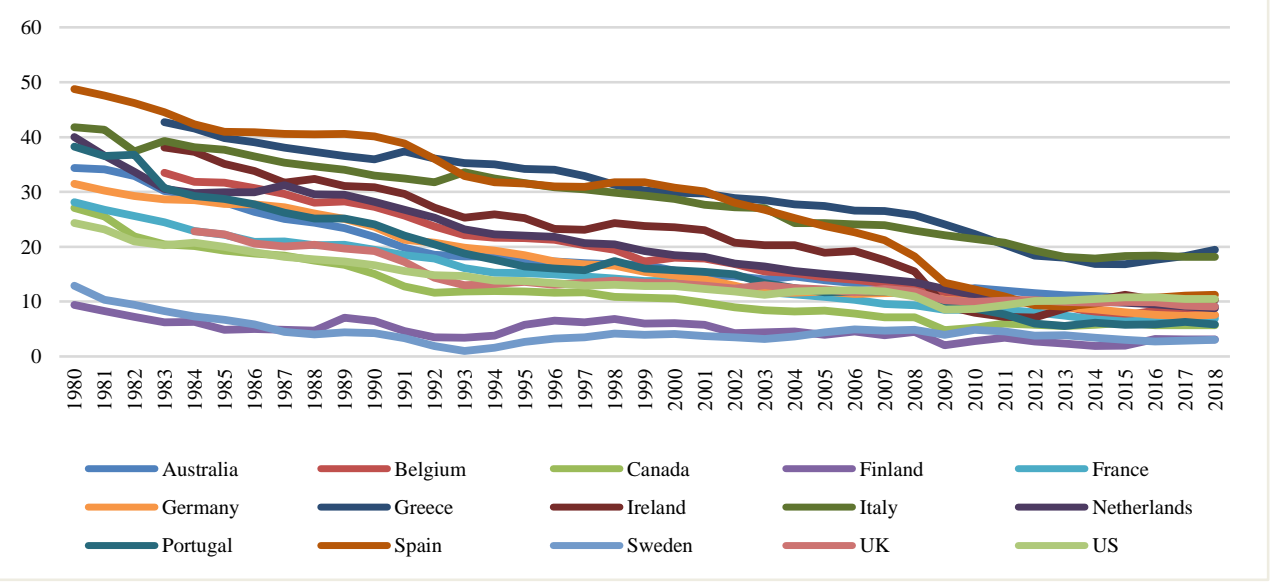

Source: OECD, <https://stats.oecd.org/\#>, 10.01.2020.

In middle-income countries, there is not a single trend of the gender gap in employment like in western countries. Different countries have different trends. The trajectory of the gender gap in some middle-income countries has been declining like in Brazil, Mexico, or Iran but in the other middle-income countries this trend is stable or increasing as in Lebanon, Turkey, or China. Although there are minor improvements, the gender gap in employment in middle-income countries is still high and the women's employment rate is still low. The 2016 average female employment rate of 27 middleincome countries subject to the analysis is about $44 \%$ and their average gender gap is almost $23 \%$. These values show that there are many stages to be overcome in women's employment in these countries (<https://www.ilo.org >). 
Figure: 3

Gender Employment Gap in Selected Middle-Income Countries

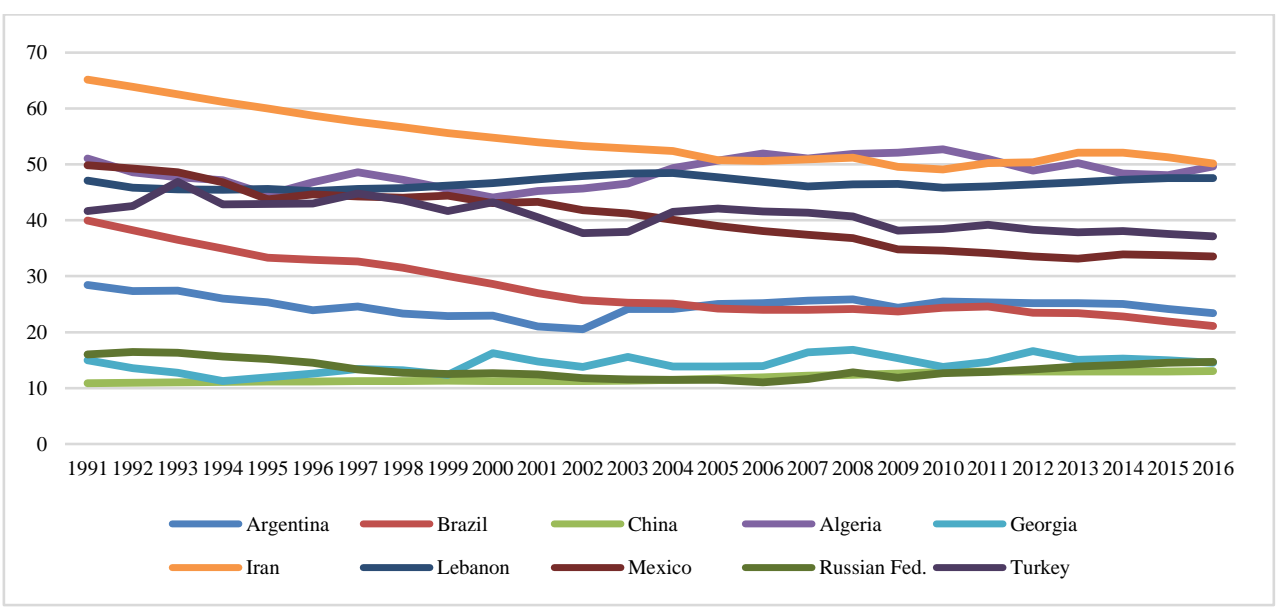

Source: ILO, <https://www.ilo.org>, 10.01.2020.

In the World Bank report (2013) it is stated that just 13 middle-income countries from 101 in the 1960s managed to reach high-income level by 2008. Unlike other middle-income countries which fail to be high-income, these countries also managed to increase women's employment rate. For example, Spain, one of these 13 countries, managed to increase female employment from $20 \%$ in the 1980 s to $44 \%$ in 2019 . Or Korea, which is shown as a success story to middle-income countries, managed to increase its female employment, which was $40 \%$ in the 1980 s, to $52 \%$ by 2019 . In Singapore or Israel, the situations are not different. The female employment rate increased from $42 \%$ to approximately $58 \%$ in Singapore and $34 \%$ to approximately $57 \%$ in Israel in the same period.

\section{Review of Existing Literature}

The seminal work of Gill \& Kharas (2007) was the first attempt to describe getting stuck in the middle-income trap. Then, the phrase "middle-income trap" has become the most debated topic. Many studies recently have addressed how middle-income countries should try to avoid being stuck in this trap. Literature on how to deal with this trap mainly focuses on innovation, technology, or growth strategy i.e., productivity growth.

Total factor productivity growth slowdown is identified as one of the main factors of growth slowdown that causes the middle-income trap. Eichengreen et al. (2012), using international data construct a sample of cases where fast-growing economies slow down. The results indicate that fast-growing countries slow down, and the growth rate downshifts by at least 2 percentage points. The growth slowdowns occur at per capita incomes of about US\$ 17,000 in year-2005 constant international prices. They point out that growth slowdowns are related to the productivity growth slowdowns and $85 \%$ of the slowdown in 
the rate of growth is driven by the slowdown in the rate of total factor growth. Daude \& Fernandez-Arias (2010) find that total factor productivity is the key factor; low and slow productivity growth are explanatory for Latin America's low income relative to high-income economies. Wu (2014) analyses the middle-income trap within the framework of productivity growth. The results indicate that productivity has an important role in sustaining economic growth in high-income economies. Wu also states that few middle-income countries which became high-income economy have benefited more from productivity growth than the others.

The studies by Felipe et al. (2012) and Eichengreen et al. (2013) focused on export strategies. Felipe et al (2012) conclude that middle-income countries have to acquire a comparative advantage with sophisticated and well-connected products. It is the most direct strategy to become a high-income country or escaping from the middle-income trap. Eichengreen et al. (2013), extend the analysis of earlier work and analyse the incidence and correlates of growth slowdowns in rapidly growing middle-income economies. Their new results show that (1) the growth slowdowns are less in some countries where the population has a higher level of secondary and tertiary education, (2) exports of high-technology intensive products reduce the possibility of growth slowdowns.

Some studies have evaluated innovation, export, and productivity argument into a general frame for the middle-income trap. Lee \& Narjoko (2015) emphasize that innovation and productivity should be further intensified to becoming a high-income country. And government support should be extended for exporters, especially SMEs. Vivarelli (2015) offers an exit strategy from the middle-income trap based on capability building, structural change, innovation, and entrepreneurship.

Wang (2016) and Köse \& Çınar (2018) offer an institutional analysis of the middleincome trap. Wang (2016) proposes a political-economic explanation and emphasizes the policies that support a middle-income country switch to technological progress and sustainable growth led by innovation. Wang (2016) also analyses the political institutions that allow for these policies. Köse and Çınar (2018) provide an institutional analysis for Turkey and many other middle-income countries. They conclude that it would be very hard to reach the upper-income level for middle-income countries such as Turkey without addressing their deficiencies in political and economic institutions.

More recently Öztürk (2015), Zou (2018), and Kabir \& Ahmed (2019) offered alternative approaches, emphasizing income inequality, equal opportunity, and middle-class income share, to avoid the middle-income trap. To understand the impact of the income, the share of the middle class in avoiding the trap Öztürk (2015) explores the link between the middle-class income share and economic growth. The results show that the key growth factors including the middle class, innovation, productivity, and foreign direct investment have a diminishing marginal effect on economic growth. Another important result shows that the share of middle-income deciles plays an important role in avoiding the trap. Zou (2018) addresses whether a country could avoid the middle-income trap with a historical 
approach. Zou (2018) stresses the importance of the manufacturing sector and technological capacities for avoiding the trap. The suggestion of this paper to the Chinese economy for the achieve this goal is the provision of equal opportunities to all citizens. Kabir \& Ahmed (2019) investigate the underlying factor of the middle-income trap. They conclude that foreign direct investment and the population of dependents are related to the lower-middleincome trap. They also show that income inequality and foreign aid assistance are associated with the upper-middle-income trap.

The study by Mare et al. (2015), to the best of our knowledge, is the first and only study conducted on the relationship between gender issues and the middle-income trap. They argue that the effective use of skills and abilities of migrants contributing to the middleincome trap at a national level is not well managed in Thailand's case. And also, their middle-income trap approach based on gender approaches shows that a combination of insufficient education, limited skills, a lack of aspiration, and the gendered economy has trapped both women and men in low-level economic activity.

\section{Data Description, Empirical Framework, and Analysis}

A panel logit model is used to examine the role of women's employment as well as other variables commonly used in avoiding the middle-income trap. This section describes the variables and data, presents the estimation methods and the estimation results.

\subsection{Variables and Data}

To analyse the impact of the women's employment rate in avoiding the middleincome trap, a panel logit model is employed. In this analysis, the impact of the women's employment rate on the possibility of an upper-middle-income country being a high-income economy is investigated. The country sample included in the analysis is based on the classification of upper-middle-income economies of the World Bank. In this classification, upper-middle-income economies are those with a GNI per capita between \$3,996 and $\$ 12,375$ and there are 60 countries in this income segment. 27 countries with suitable data for the balanced panel are selected from these 60 countries and included in the analysis. The list of the countries subject to the analysis is located in the Appendix. To estimate the model in 27 countries the annual time series for the period 1995-2016 is used. Because of data availability, this paper focuses on this period.

This study employs cross-section data of 27 countries to estimate the effect of the female employment rate and some other related variables on the probability of the transition of an upper-middle-income country to a high-income economy. For this purpose, five variables have been used. The other four variables except the female employment are commonly suggested arguments in the literature for avoiding the middle-income trap (Ozturk, 2015). Based on previous studies, and the data availability, the following variables for a logit model are specified: 
- The dependent variable is Real GDP per capita in 2011US\$. The dependent variable GDP is discrete, is equal to 1 if a country has moved up to the high-income level (higher than 12375) and 0 if the country has remained in the upper-middleincome level (lower than 12376). Real GDP data obtained from the Maddison Project Database (MPD).

- One of the independent variables is the female employment rate from International Labor Organization (ILO). This variable based on the employment-to-population ratio is the number of persons who are employed as a percent of the total of the working-age population (working age is +15 ). The other independent variable is productivity from ILO. Labor productivity is defined as output per worker. Also, to examine the impact of innovation, the patent variable is used as a proxy measure of innovation from the World Bank. Patent applications as a proxy of innovation are worldwide patent applications filed through the Patent Cooperation Treaty procedure or with a national patent office. Patent applications by resident data obtained from the World Bank Database. Furthermore, the economic freedom variable is included in the analysis to determine the impacts of institutions on the transition from upper-middle-income to high income. The index of Economic freedom annual data is released for the 1995-2020 period by the Heritage Foundation.

In this study, a panel logit model is employed to estimate the effects of the female employment rate on the probability of the transition of an upper-middle-income country to a high-income economy. The data of all variables used in the model estimated in the analysis are given in Table 1 and Table 2. Tale 1 presents the variable definitions, and the summary statistics of the data are given in Table 2 .

Table: 1

Data Set

\begin{tabular}{lll}
\hline Title & Variables & Sources \\
\hline GDP & Discrete variable 0 or 1; Real GDP per capita in 2011US\$ & MPD \\
Female Emp. & Female employment-to-population ratio & ILO \\
Productivity & Output per worker (US\$) & ILO \\
Innovation & Patent applications, resident & World Bank \\
Institution & Economic Freedom Index & Heritage Foundation \\
\hline
\end{tabular}

Table: 2

\section{Summary Statistics}

\begin{tabular}{lrrrr}
\hline Variable & Obs. & Mean & Std. Dev. & Min \\
\hline GDP & 594 & 10.242 .71 & 4.796 .713 & 2.170 \\
Female Emp. & 594 & 42.38832 & 14.53148 & 8.233 \\
Productivity & 594 & 17.603 .188 & 12.305 .605 & 70.701 \\
Innovation & 594 & 11.779 .39 & 83.714 .38 & 2.101 .629 \\
Institution & 594 & 56.90438 & 10.24177 & 1 \\
\hline
\end{tabular}

\subsection{Estimation Methods}

If a dependent variable based on a discrete value, a household purchased a car or not; an individual has joined a labour union or not, this dependent variable is usually represented 
by a binary choice variable $y_{i t}=1$ if the event happens and 0 if it does not for individual $i$ at time $t$. If $\mathrm{p}_{\mathrm{it}}$ is the probability that person $i$ has a car at time $\mathrm{t}$, so then $E\left(y_{i t}\right)=1 \cdot p_{i t}+0 \cdot(1-$ $\left.p_{i t}\right)=p_{i t}$, this is usually modelled as a function of relevant variable like (Baltagi, 2005; Vogelvang, 2005);

$$
\mathrm{p}_{\mathrm{it}}=\operatorname{Pr}\left[\mathrm{y}_{\mathrm{it}}=1\right]=\mathrm{E}\left(\mathrm{y}_{\mathrm{it}} / \mathrm{x}_{\mathrm{it}}\right)=\mathrm{F}\left(X_{\mathrm{it}}^{\prime} \beta\right)
$$

The probability functions are known in the econometrics literature as the logit and probit models. In case of a discrete dependent variable in this study:

$\mathrm{y}_{\mathrm{it}}=1$, if $y_{i t}^{*}>0$, if a middle-income country has moved up to a high-income economy (higher than 12375)

$\mathrm{y}_{\mathrm{it}}=0$, otherwise, if a middle-income country has remained in the middle-income level (lower than 12376)

$$
\text { where } y_{i t}^{*}=X_{i t}^{\prime} \beta+u_{i t} \text {. }
$$

The probability of a country's transition to a high-income level is dependent on observed variables. The probability of the transition of an upper-middle-income country to a high-income level is:

$$
\operatorname{Pr}\left[\mathrm{y}_{\mathrm{it}}=1\right]=\operatorname{Pr}\left[y_{i t}^{*}>0\right]=\operatorname{Pr}\left[v_{i t}>-X_{i t}^{\prime} \beta-\mu_{i}\right]=\mathrm{F}\left(X_{i t}^{\prime} \beta+\mu_{i}\right)
$$

In panel data, the presence of individual effects complicates the estimations, and this is known as the incidental parameters problem. The basic solution to the incidental parameters problem is to find a minimal sufficient statistic or $\mu_{i}$. Chamberlain (1980) shows the impossibility of estimating the parameters of this discrete choice model consistently and therefore, suggests maximizing the conditional likelihood function (Baltagi, 2005; Mierau et al., 2007):

$$
L_{c}=\prod_{i=1}^{N} \operatorname{Pr}\left(y_{i 1}, \ldots, y_{i T} / \sum_{t=1}^{T} y_{i t}\right)
$$

\subsection{Empirical Results}

In this section, a panel logit model is employed to estimate the effects of related variables on the probability of the transition of an upper-middle-income country to a highincome level. Tables 3 and 4 show the estimation results. Just before evaluating the results, it is necessary to consider model specifications. To that end, the Hausman specification test is employed for the model selection between fixed-effects logit and random effects logit models. The results of the comparison of these two models are presented in Table 3. Based on the Hausman specification test results, the $\mathrm{H}_{0}$ hypothesis is rejected. Test results show that the fixed-effects estimator seems to be a better fit with this logit model. 
Table: 3

Hausman Test for Model Selection

\begin{tabular}{lllll}
\hline & Fixed Effect Logit & Random Effect Logit & Difference & S.E. \\
\hline Female Employment & 1,054133 & 0,6360895 & 0.4180431 & 0,2223589 \\
Productivity & 0,0000226 & 0,0000103 & 0,0000123 & 0,00000402 \\
Innovation & 0,0030379 & 0,0000185 & 0,0030194 & 0,0012442 \\
Institution & $-0,2144431$ & 0,0184456 & $-0,2328886$ & 0,0869689 \\
Prob>chi2 & 0,0045 & & & \\
\hline
\end{tabular}

$H_{0}$ : difference in coefficients not systematic.

Hausman test results support the use of the fixed-effects logistic regression model. Accordingly, conditional fixed-effects logistic regression is run. Tables 4 shows the outcomes of the conditional logit regression. The model is statistically significant ( $L R=$ 338.10; $p=0$,000; Pseudo $R_{2}=0,85$ ). In column (3) of Tables 4, the odds ratios based on conditional logistic regression are given. It is found that all variables i.e., including women's employment rate, productivity innovation, and institution affect the probability of a country moving up to the high-income ladder positively. The results in detail show that a one percent increase in the women's employment ratio increases the probability of a middle-income country climbing to the high-income ladder by 2,869 . Each increase of one percent in productivity increases the probability by 1,000002 . An increase of one unit in the innovation and the institution increases the probability of a middle-income country becoming a highincome economy by respectively 1,003043 and 0,8069908 . The findings based on the conditional fixed-effects logistic regression show that the possibility of a middle-income country being a high-income economy is significantly associated with female employment rate, productivity innovation, and institution. However, the results also show that female employment is an important argument that has more impact than the other variable.

\section{Table 4. Conditional (Fixed-Effects) Logistic Regression}

\begin{tabular}{|c|c|c|c|c|}
\hline $\begin{array}{l}\text { Variables } \\
\text { (GDP is the discrete dependent variable coded } 0 \text { or } 1 \text { ) }\end{array}$ & Coefficients & Standard errors & Odds Ratio & Standard errors \\
\hline Female Employment & $1,054133 * * *$ & 0,2231723 & $2,869 * * *$ & 0,640 \\
\hline Productivity & $0,0000226 * * *$ & 0,00000405 & $1,000002 * * *$ & 0,00000405 \\
\hline Innovation & $0,0030379 * *$ & 0,0012442 & $1,003043^{* *}$ & 0,001248 \\
\hline Institution & $-0,2144431 * *$ & 0,0936983 & $0,8069908 * *$ & 0,0756137 \\
\hline Observations & \multicolumn{4}{|c|}{374} \\
\hline LR test & \multicolumn{4}{|c|}{338.10} \\
\hline P-value & \multicolumn{4}{|c|}{0,0000} \\
\hline Pseudo R2 & \multicolumn{4}{|c|}{0,8504} \\
\hline
\end{tabular}

\section{Conclusions}

Being in a middle-income country or becoming stuck in the middle-income is not an irreversible situation. There are inspiring good examples of countries such as South Korea and Singapore in history. Although the literature often refers to key arguments such as technology, innovation, and efficiency as a strategy to exit the middle-income trap, the structural differences between high-income countries and middle-income countries are not just these arguments. This paper agrees with this valuable view but extends it in a different aspect drawing attention to the ignored role of women. Thus, this paper differs from existing middle-income trap literature because of considering the gender issues. The female 
employment structure sheds light on another distinction between these countries. Today, the women's employment rate is high in many western high-income countries, and the gap between male and female employment has declined compared to the past. But we cannot easily say the same thing for middle-income countries. In middle-income countries, there is not a single trend of the gender gap in employment like in western countries because, in some countries, the gender gap continues to open rather than close.

In many middle-income countries, women are seen just as potential caregivers. Care is often considered to be an activity that requires feminine qualities. Limiting women only to the role of caregivers causes them to build their identity only in terms of care. As a natural consequence of this their employment opportunities in the market are narrowing and financial pressure on families is also increasing (Kremer, 2007). Kremer (2007) states that in many countries, women constitute a "massive untapped labour reserve." We can easily use this expression for the women of middle-income countries. In these countries, women are a source of "the massive untapped labour reserve" that can support further economic development. In this study, women's employment is considered as another escape strategy from the middle-income trap. In line with this perspective, a panel logit model is employed to estimate the effects of women's employment rate and other related variables on the probability of the transition of an upper-middle-income country to a high-income level. The findings based on the conditional fixed-effects logistic regression show that the possibility of a middle-income country being a high-income economy is significantly associated with the women's employment rate, productivity, innovation, and institution. However, the results also show that women's employment is an escape strategy that has more impact than the other variable. According to these results, it is seen that various improvements should be made in the employment of women to avoid the middle-income trap. These improvements would start with rethinking gender roles in the social and economic spheres. Therefore, countries trying to deal with the middle-income trap should, first of all, abandon the understanding that women are the sole owners of family responsibilities and support the employment of women with their social policies within the framework of the defamilialization approach.

Since the 1970s, a "women's revolution" has been taking place in many countries, which has caused a transformation in gender roles with the participation of women in lifelong employment. However, the restriction of the role attributed to women within the household in some countries indicates that the women's revolution is incomplete or not realized at all, while making them the sole owner of family care responsibilities. The fact that women must fulfill their responsibilities in the labor market without any disrupting of their care obligations is a deterrent factor limiting women's participation in the labor force. On the other hand, difficulties faced by women due to the male-dominated nature of established labor markets is another deterrent factor that limits women's participation in the labor force. Such factors make it difficult for women to access full-time employment, while also placing them in a secondary position in employment. Care responsibilities and the dominant characteristics of the labor market, as Buğra (2014) stated, make it difficult to solve the problems faced by women and the burden of economic independence is heavy 
under these conditions. The difficulties women face in the labor market and the difficulties they face in accessing the labor market (from household to market) are much more stratified and difficult than women can overcome alone. Therefore, governments should stop leaving the solution only to the family in the care responsibilities. The issue of prevailing genderbased inequalities in the labor market should also be taken seriously as a policy priority of governments. As a result, countries that want to get out of the middle-income trap should support women's transition from households to paid employment through institutional and stable social policies in order to benefit from women's untapped labor reserves.

\section{References}

Agénor, P.R. \& O. Canuto \& M. Jelenic (2012), “Avoiding Middle-Income Growth Traps”, Economic Premise, (98), World Bank.

Baltagi, B. (2005), Econometric Analysis of Panel Data, John Wiley \& Sons.

Bolt, J. \& R. Inklaar \& H. de Jong \& J.L. van Zanden (2018), Maddison Project Database.

Buğra, A. (2014), "Giriş”, in: A. Buğra \& Y. Özkan (eds.), Akdeniz'de Kadın İstihdamının Seyri, İstanbul, İletişim Yayınları, 9-28.

Daude, C. \& E. Fernández-Arias (2010), On the Role of Productivity and Factor Accumulation in Economic Development in Latin America and the Caribbean, OECD Publishing.

Eichengreen, B. \& D. Park \& K. Shin (2012), "When Fast-Growing Economies Slowdown: International Evidence and Implications for China", Asian Economic Papers, 11(1), 4287.

Eichengreen, B. \& D. Park \& K. Shin (2013), "Growth Slowdowns Redux: New Evidence on the Middle-Income Trap", (No. w18673), Working Paper, National Bureau of Economic Research.

Felipe, J. \& A. Abdon \& U. Kumar (2012), "Tracking the Middle-Income Trap: What is It, Who is in It, and Why?", Levy Economics Institute Working Paper.

Gill, I.S. \& H. Kharas (2015), “The Middle-Income Trap Turns Ten”, World Bank Policy Research Working Paper.

Gill, I.S. \& H. Kharas (eds.) (2007), An East Asian Renaissance: Ideas for Economic Growth, The World Bank.

Kabir, M.A. \& A. Ahmed (2019), “An Empirical Approach to Understanding the Lower-Middle and Upper-Middle Income Traps”, International Journal of Development Issues, 18(2), 171190.

Köse, T. \& K. Çınar (2018), “Türkiye Orta Gelir Tuzağından Kaçabilir mi? İktisadi Gelişmeye Kurumsalcı Bir Yaklaşım”, Sosyoekonomi, 26(38), 151-170.

Kremer, M. (2007), How Welfare States Care: Culture, Gender, and Parenting in Europe, Amsterdam: Amsterdam University Press.

Le Mare, A. \& B. Promphaking \& J. Rigg (2015), "Returning Home: The Middle-Income Trap and Gendered Norms in Thailand", Journal of International Development, 27(2), 285-306.

Lee, C. \& D. Narjoko (2015), "Escaping the Middle-Income Trap in Southeast Asia: Micro Evidence on Innovation, Productivity, and Globalization", Asian Economic Policy Review, 10(1), 124-147. 
Mierau, J.O. \& R. Jong-A-Pin \& J. De Haan (2007), "Do Political Variables Affect Fiscal Policy Adjustment Decisions? New Empirical Evidence", Public Choice, 133(3-4), 297-319.

Ozturk, A. (2016), "Examining the Economic Growth and the Middle-Income Trap from the Perspective of the Middle Class", International Business Review, 25(3), 726-738.

Vivarelli, M. (2016), "The middle-income trap: a way out based on technological and structural change", Economic Change and Restructuring, 49(2-3), 159-193.

Vogelvang, B. (2005), Econometrics: Theory and Applications with Eviews, Pearson Education.

Wang, Y. (2016), "The Political Economy of the Middle-Income Trap: Implications for Potential Growth", Asian Development Review, 33(2), 167-181.

Woo, W.T. (2012), "China Meets the Middle-Income Trap: The Large Potholes in the Road to Catching-up", Journal of Chinese Economic and Business Studies, 10(4), 313-336.

World Bank (2013), China 2030: Building a Modern, Harmonious, and Creative Society,

Development Research Center of The State Council \& The People's Republic of China, World Bank Publications.

$\mathrm{Wu}, \mathrm{Y}$. (2014), "Productivity, Economic Growth and the Middle-Income Trap: Implications for China", Frontiers of Economics in China, 9(3), 460-483.

Yao, Z. (2015), "How Can China Avoid the Middle-Income Trap?", China \& World Economy, 23(5). 26-42.

\section{Appendix}

\section{List of Countries}

Argentina, Armenia, Azerbaijan, Bulgaria, Belarus, Brazil, China, Colombia, Cuba, Dominican Republic, Algeria, Ecuador, Georgia, Guatemala, Iran (Islamic Republic of), Jamaica, Jordan, Kazakhstan, Mexico, Malaysia, Peru, Romania, Russian Federation, Thailand, Turkey, Venezuela (Bolivarian Republic of), South Africa. 